\title{
First evidence of a spawning site of the endangered fish Brycon orbignyanus (Valenciennes, 1850) (Characiformes, Bryconidae) in the Middle Uruguay River, Brazil
}

Primeira evidência de um local de desova do peixe ameaçado de extinção Brycon orbignyanus (Valenciennes, 1850) (Characiformes, Bryconidae) no Médio rio Uruguai, Brasil

David Augusto Reynalte-Tataje ${ }^{1 *}$ (D), Marlon da Luz Soares ${ }^{1}$ (D), Marthoni Vinicius Massaro ${ }^{1}$ (D), Rodrigo Bastian $^{1}$ (D), Fernando Mayer Pelicice² (D)

${ }^{1}$ Universidade Federal da Fronteira Sul - UFFS. Rua Jacob Reinaldo Haupenthal, 1580, CEP 97900-000, Cerro Largo, RS, Brasil

${ }^{2}$ Núcleo de Estudos Ambientais, Universidade Federal do Tocantins - UFT, Rua 3, Quadra 11 17, Jardim dos Ipês, CEP 77500-000, Porto Nacional, TO, Brasil

*e-mail: david.tataje@uffs.edu.br

Cite as: Reynalte-Tataje, D.A. et al. First evidence of a spawning site of the endangered fish Brycon orbignyanus (Valenciennes, 1850) (Characiformes, Bryconidae) in the Middle Uruguay River, Brazil. Acta Limnologica Brasiliensia, 2020, vol. 32, e23.

Abstract: Aim: This study provides the first direct evidence about the location of a spawning site of Brycon orbignyanus (Valenciennes, 1850) in the Middle Uruguay River. Methods: Sampling was carried out with a plankton net $(500 \mu \mathrm{m})$ in November 2017 in the Uruguay River near the confluence with the Piratinim River, southern Brazil. Eggs were sorted in the field, and to confirm species identity we used the live ichthyoplankton technique. Results: We captured 47 eggs of B. orbignyanus in the channel of the Uruguay River, characterized by fast flow, shallow depth (approximately $3 \mathrm{~m}$ ) and rocky bottom, located a few kilometers upstream from its confluence with the Piratinim River. Eggs are spherical, well hydrated, semi-dense, transparent and non-adhesive, with a single membrane and large perivitelline space. Total diameter varied between 3,500 and 4,000 $\mu \mathrm{m}$. Eggs were in early stages of embryonic development, and cells showed 8, 16 or 32 blastomeres. A total of 16 eggs hatched into larvae in the plastic bags. Larvae hatched approximately 18 hours after incubation, and took 14 days to become juvenile. Conclusion: This seems to be the first record of a spawning site of $B$. orbignyanus in the La Plata River Basin, and points to the relevance of the Middle Uruguay River as a recruitment area for this endangered species.

Keywords: reproduction; rheophilic fish; dams; eggs; ichthyoplankton.

Resumo: Objetivo: Este estudo fornece a primeira evidência direta sobre a localização de um sítio de desova de Brycon orbignyanus (Valenciennes, 1850) no médio rio Uruguai. Métodos: As amostragens foram realizadas com uma rede de plâncton $(500 \mu \mathrm{m})$ durante novembro de 2017 no rio Uruguai, próximo a confluência com o rio Piratinim, RS, Brasil. A triagem foi realizada em campo e a identificação da espécie foi feita utilizando a técnica do ictioplâncton vivo. Resultados: Foram capturados 47 ovos de B. orbignyanus na calha principal do rio Uruguai, em um trecho caracterizado por fluxo rápido, baixa profundidade $(3 \mathrm{~m})$ e fundo rochoso, localizado alguns quilómetros acima da confluência com o rio Piratinim. Os ovos são esféricos, bem hidratados, semi-densos, transparentes e não-adesivos, com uma única membrana e grande espaço perivitelino. O diâmetro total variou entre 3.500 e $4.000 \mu \mathrm{m}$. Os ovos estavam em estágio inicial de desenvolvimento embrionário e as 
células apresentavam 8, 16 ou 32 blastômeros. Um total de 16 ovos se desenvolveram em larva nos recipientes. As larvas eclodiram aproximadamente após 18 horas de incubação, e levaram 14 dias para virar juvenis. Conclusáo: Esse parece ser o primeiro registro de evidência de um local de desova de B. orbignyanus na Bacia do Rio da Prata, e indicam a relevância do médio rio Uruguai como área de recrutamento para essa espécie ameaçada.

Palavras-chave: reprodução; peixe reofílico; represas; ovos; ictioplâncton.

The conservation of migratory fishes is challenging. Although conservation efforts have been applied, resources are limited and some measures have shown ineffective results (Agostinho et al., 2005). In addition, habitat integrity and ecosystem functioning in the Neotropics have been severely affected by a myriad of unsustainable activities (Pelicice et al., 2017), threatening the maintenance of fish diversity in the long term. In this sense, the definition of priority areas for conservation, particularly to preserve spawning and nursery sites, may represent the most adequate strategy (Agostinho et al., 2005). However, these areas are difficult to locate, especially for endangered species, which eventually have low population sizes, decreased recruitment, or demand specific sampling methodologies (i.e., that avoid death and injuries).

The genus Brycon includes 44 valid fish species (Fricke et al., 2020), and many of them display migratory behavior. These fishes are mid to largesize, distributed across the major hydrographic basins of South America, and in most of the Caribbean and Atlantic coastal systems (Lima, 2017). The "piracanjuba" Brycon orbignyanus Valenciennes, 1850 is a large-sized rheophilic species native to the Río de La Plata Basin, i.e. the Paraná, Paraguay and Uruguay river systems (Lima, 2017). Populations of this species have been extensively impacted by habitat loss, fragmentation and degradation, particularly due to the loss of riparian vegetation, spawning sites and nursery areas. Currently, the piracanjuba is listed as endangered in Brazil (ICMBio, 2018). The maintenance of B. orbignyanus in different areas of the La Plata Basin will depend ultimately on the identification of areas with high ecological relevance (e.g. spawning and rearing sites), where conservation efforts must be applied.

B. orbignyanus is found along the Uruguay River, but the distribution of spawning areas remains unknown. In this context, this study sampled fish eggs in the Middle Uruguay River and provided the first direct evidence about the location of a spawning site, through the capture of eggs in early stages of development, identified by the live ichthyoplankton technique. This information is important to guide conservation plans, particularly to define priority areas in the Middle Uruguay River, a region targeted for hydropower expansion.

The site is located in the Middle Uruguay River Basin, a fluvial segment of about $800 \mathrm{~km}$ composed of rapids and pools, mainly in the upstream section. The sampling site is characterized by the presence of rapids, fluvial islands and riparian forests; the channel is $1,250 \mathrm{~m}$ wide, with an average depth of $7 \mathrm{~m}$ (Figure 1).

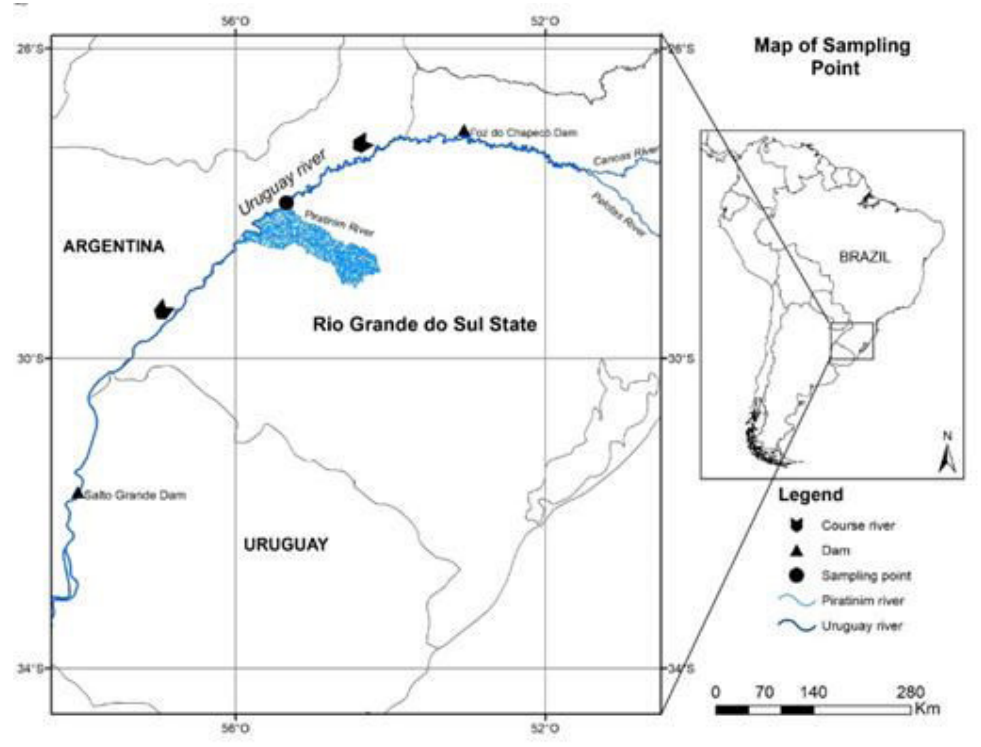

Figure 1. Location of the study area (Middle Uruguay River) and the sampling site. 
Figure 1

Samples were collected in November 2017 in the early evening (around 20h00), when the river level was increasing. Water temperature was $26.5^{\circ} \mathrm{C}$, water velocity was $1.27 \mathrm{~m} / \mathrm{s}$ and water transparency was about $70 \mathrm{~cm}$. Early life forms were collected with a conical-cylindrical plankton net with $500 \mu \mathrm{m}$ mesh size, towed against the current by a motorized boat at slow speed for 5 minutes. We collected four samples at the subsurface. In the field, piracanjuba eggs were sorted, counted (see Reynalte-Tataje et al., 2004 for details) and then incubated in plastic bags containing oxygenated water to confirm the identification (live ichthyoplankton technique; Reynalte-Tataje \& Zaniboni-Filho, 2008). All piracanjuba larvae that hatched were taken to the Laboratory of Ecology at the Universidade Federal da Fronteira Sul (UFFS) and kept in $50 \mathrm{~L}$ aquaria in a closed recirculation system. They were fed initially with Artemia sp. and later with larvae of other fish and tadpoles. The larvae and juveniles were fed ad libitum twice a day. A larvae sample was deposited in the fish collection at the Universidade Estadual de Maringá (NUP 20902).

In total, we captured 47 eggs of B. orbignyanus in the Middle Uruguay River, locality of Santo Isidro ( $\left.28^{\circ} 44^{\prime} 43^{\prime \prime} \mathrm{N}, 55^{\circ} 25^{\prime} 42^{\prime} \mathrm{W}\right)$, São Nicolau, RS, Brazil. Eggs were captured in the middle of the channel, a site characterized by fast flow, shallow depth (approximately $3 \mathrm{~m}$ ) and rocky bottom. This site is located a few kilometers upstream from the confluence between the Piratinim and Uruguay rivers. In addition to piracanjuba eggs, we collected eggs from other migratory species: Pseudopimelodus mangurus (30) and Prochilodus lineatus (72). They were at early stages of embryonic development. Of all eggs captured in these samples, $24 \%$ belonged to migratory species.

Piracanjuba eggs were in early stages of embryonic development, and cells showed 8, 16 or 32 blastomeres. Eggs are spherical, well hydrated, semi-dense, transparent and non-adhesive, with a single membrane and large perivitelline space. Total diameter varied between 3,500 and 4,000 $\mu \mathrm{m}$. A total of 16 eggs hatched into larvae in the plastic bags. Larvae hatched approximately 18 hours after incubation in the bags, and took 14 days to become juvenile. These fish, with approximately $40 \mathrm{~mm}$ and 30 days, were released in the river at the same place where eggs were captured (Figure 2).

Figure 2

To the best of our knowledge, this is the first direct evidence of the location of a spawning site of B. orbignyanus in the La Plata River Basin. Previous information about spawning sites came from indirect evidence, where larvae location and development rates were based on water velocity to estimate spawning grounds located upstream (Worthington et al., 2014). The identification of eggs soon after fertilization indicated that the Uruguay River, upstream from the confluence with the Piratinim River, is a spawning site (3-5 km upstream)

In the Neotropical region, long-distance migratory species usually reproduce during warm

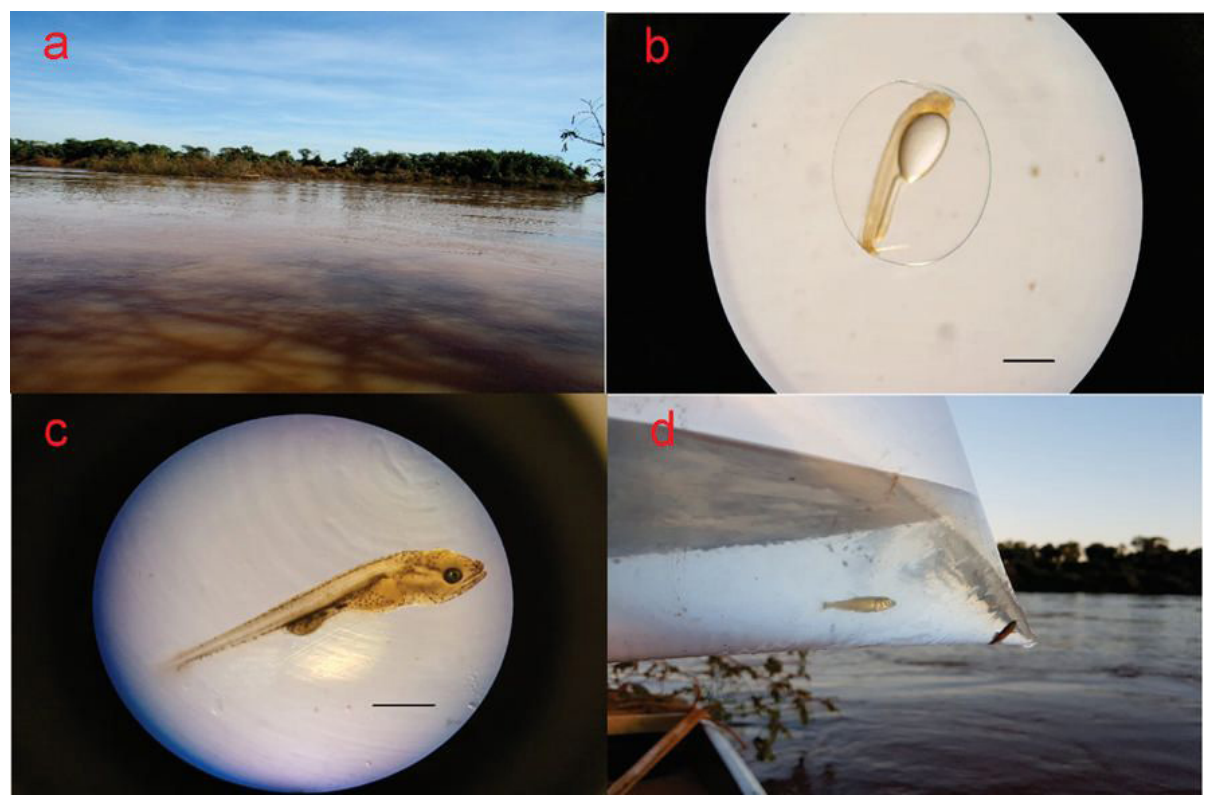

Figure 2. Sampling area (a); egg with embryo ready to hatch (b); larvae in the pre-flexion stage (c); juvenile released at the confluence between the Piratinim and Uruguay rivers (d). Scale: Bar $=10 \mathrm{~mm}$. 
and wet months (Austral spring and summer), with greater intensity between November and January (Reynalte-Tataje et al., 2012a). Reproduction is associated with increasing temperatures, precipitation, electrical conductivity, water level and flow (Reynalte-Tataje et al., 2012b; Lopes et al., 2019). These conditions were found during our sampling date (November), i.e. the river level was rising, temperature was high and water transparency was relatively low. On the other hand, the fact of having found eggs of other migratory species in addition to piracanjuba eggs and still in a relatively high proportion indicates that the conditions found near the mouth of the Piratinim River may be important for reproduction. The spawning of migratory fish in environments close to the mouth of the Uruguay River has also been reported by Hermes-Silva et al. (2009) and Reynalte-tataje et al. (2012b). These authors indicate that the physicochemical variations such as electrical conductivity, temperature and turbidity that are verified in these confluence areas can act as a final trigger in the spawning of these fish. Because these are the first samples taken at the mouth of the Piratinim River, future studies must indicate whether spawning activity is sporadic or consistent, which migratory species use this environment for spawning, and potential drivers governing reproductive dynamics.

It is worth noting that the live ichthyoplankton technique was crucial to confirm identification, since it allows the tracking of development from egg to juvenile. This method has been widely used in the upper and middle Uruguay during the last 15 years, covering different sampling stations (ReynalteTataje \& Zaniboni-Filho, 2008). However, it was the first time that this technique recorded and identified piracanjuba eggs - in a relevant number given the limited sampling effort (towing time). This method is therefore an efficient alternative to identify spawning sites (Reynalte-Tataje et al., 2008) as well as to define kinship through genetic studies, as currently developed in the Uruguay River (Ribolli et al., 2016). Implicit limitations include the need for adequate infrastructure close to the sampling sites, and advanced knowledge about incubation and fish larviculture (Reynalte-Tataje \& Zaniboni-Filho, 2008).

Currently, river regulation is the main factor behind the decline and collapse of migratory fishes in the Neotropical region, particularly via fragmentation, loss of fluvial environments, and changes in the natural flow regime (Pelicice et al., 2017). Free-flowing stretches, with natural conditions, are rare along the Uruguay River and many other parts of the La Plata Basin (ReynalteTataje et al., 2012b; Agostinho et al., 2016). The Middle Uruguay River, however, still preserves fluvial sections, such as the site where we collected eggs of B. orbignyanus. Moreover, this spawning site is located ca. $140 \mathrm{~km}$ upstream from the floodplain in the São Borja region, where larvae may find favorable conditions to grow. Consequently, this river section includes both spawning and nursery sites, implying that it has high conservation value. We highlight, however, that the Middle Uruguay River has been targeted for hydropower development, with the proposed construction of the Garabi-Panambi hydroelectric complex (generation of $2200 \mathrm{MW}$ ), which includes two dams to be installed downstream from the Turvo State Park. The hydroelectric complex, particularly Garabi Dam, will flood permanently the spawning site identified in this study.

The context of the Middle Uruguay River is highly relevant for the conservation of remnant populations of $B$. orbignyanus, especially because this species, like other migratory fishes, declined or disappeared from different reaches of the $\mathrm{La}$ Plata Basin. The presence of an extensive fluvial section in the Middle Uruguay River, with lotic environments and floodplain areas, probably enabled this migratory species to complete its life cycle and maintain populations. The information presented in this study, therefore, is crucial to guide hydropower development in this region.

\section{References}

AGOSTINHO, A.A., GOMES, L.C., SANTOS, N.C.L., ORTEGA, J.C.G. and PELICICE, F.M. Fish assemblages in Neotropical reservoirs: Colonization patterns, impacts and management. Fisheries Research, 2016, 173(1), 26-36. http://dx.doi. org/10.1016/j.fishres.2015.04.006.

AGOSTINHO, A.A., THOMAZ, S.M. and GOMES, L.C. Conservation of the biodiversity of Brazil's inland waters. Conservation Biology, 2005, 19(3), 646-652. http://dx.doi.org/10.1111/j.15231739.2005.00701.x.

FRICKE R., ESCHMEYER, W.N. and VAN DER LAAN, R, eds. Eschmeyer's Catalog of Fishes: Genera, Species, References [online]. San Francisco, CA: California Academy of Science; 2020 [viewed 23 Abr. 2020]. Available from: http://researcharchive. calacademy.org/research/ichthyology/catalog/ fishcatmain.asp

HERMES-SILVA, S., REYNALTE-TATAJE, D.A. and ZANIBONI-FILHO, E. Spatial and temporal 
distribution of Ichthyoplankton in the Upper Uruguay River, Brazil. Brazilian Archives of Biology and Technology, 2009, 52(4), 933-944. http://dx.doi. org/10.1590/S1516-89132009000400017.

INSTITUTOCHICO MENDES DECONSERVAÇÃO DA BIODIVERSIDADE - ICMBio. Livro Vermelho da Fauna Brasileira Ameaçada de Extinção: Volume VI - Peixes. In: Instituto Chico Mendes de Conservação da Biodiversidade, org. Livro Vermelho da Fauna Brasileira Ameaçada de Extinção. 1a ed. Brasília: ICMBio, 2018, pp. 1-1232.

LIMA, F.C.T. A revision of the cis-andean species of the genus Brycon Müller \& Troschel (Characiformes: Characidae). Zootaxa, 2017, 4222(1), 1-189. http://dx.doi.org/10.11646/zootaxa.4222.1.1. PMid:28187640.

LOPES, J.M., ALVES, C.B.M., PERESSIN, A. and POMPEU, P.S. Upstream and downstream migration speed of Prochilodus costatus (Characiformes: Prochilodontidae) in upper São Francisco basin, Brazil. Neotropical Ichthyology, 2019, 17(2), e180072. http://dx.doi.org/10.1590/1982-0224-20180072.

PELICICE, F.M., AZEVEDO-SANTOS, V.M., VITULE, J.R.S., ORSI, M.L., LIMA JUNIOR, D.P., MAGALHÂES, A.L.B., POMPEU, P.S., PETRERE, $M$. and AGOSTINHO, A.A. Neotropical freshwater fishes imperilled by unsustainable policies. Fish and Fisheries, 2017, 18(6), 1119-1133. http://dx.doi. org/10.1111/faf.12228.

REYNALTE-TATAJE, D.A. and ZANIBONI-FILHO, E. 2008. Biologia e identificação de ovos e larvas de peixes do alto rio Uruguai, Brasil. In: E ZANIBONIFILHO and A.P.O. NUNEER, eds. Reservatório de Itá. Estudos ambientais, desenvolvimento de tecnologias de cultivo e conservação da ictiofauna. Florianópolis: Editora UFSC, 2008, pp. 229-256.

REYNALTE-TATAJE, D.A., HERMES-SILVA, S., SILVA, P.A., BIALETZKI, A. and ZANIBONIFILHO, E. Locais de crescimento de larvas de peixes na região do Alto Rio Uruguai (Brasil). In: E. ZANIBONI-FILHO and A.P.O. NUÑER, eds. Reservatório de Itá. Estudos ambientais, desenvolvimento de tecnologia e conservação da ictiofauna. Florianópolis: Editora UFSC, 2008, pp. 159-194.

REYNALTE-TATAJE, D.A., NUÑER, A.P.O., NUNES, M.C., GARCIA, V., LOPES, C.A. and ZANIBONI-FILHO, E. Spawning of migratory fish species between two reservoirs of the upper Uruguay river, Brazil. Neotropical Ichthyology, 2012a, 10(4), 829-835. http://dx.doi.org/10.1590/S167962252012000400016 .

REYNALTE-TATAJE, D.A., ZANIBONI-FILHO, E. and ESQUIVEL, J.R. Embryonic and larvae development of piracanjuba, Brycon orbignyanus Valenciennes, 1849 (Pisces, Characidae). Acta Scientiarum. Biological Sciences, 2004, 26(1), 67-71. http://dx.doi.org/10.4025/actascibiolsci.v26i1.1660.

REYNALTE-TATAJE, D.A., ZANIBONI-FILHO, E., BIALETZKI, A. and AGOSTINHO, A.A. Temporal variability of fish larvae assemblages: influence of natural and anthropogenic disturbances. Neotropical Ichthyology, 2012b, 10(4), 837-846. http://dx.doi. org/10.1590/S1679-62252012000400017.

RIBOLLI, J., MIÑO, C.I., ZANIBONI-FILHO, E., DE SOUZA GUERREIRO, T.C., REYNALTETATAJE, D.A., DE FREITAS, P.D. and GALETTI JUNIOR, P.M. Preliminary insights into the genetic mating system of Neotropical Salminus brasiliensis: kinship assignment and parental reconstruction reveal polygynandry. Ichthyological Research, 2016, 63(1), 187-191. http://dx.doi.org/10.1007/s10228015-0487-2.

WORTHINGTON, T.A., BREWER, S.K., FARLESS, N., GRABOWSKI, T.B. and GREGORY, M.S. Interacting effects of discharge and channel morphology on transport of semibuoyant fish eggs in large, altered river systems. PLoS One, 2014, 9(5), e96599. http://dx.doi.org/10.1371/journal. pone.0096599. PMid:24802361.

Received: 17 March 2020 Accepted: 20 July 2020

Associate Editor: André Andrian Padial. 